\title{
STRATEGIES FOR STRENGTHENING THE CAPACITY OF GRASSROOTS WOMEN IN NIGERIA TO OVERCOME POVERTY
}

\author{
Angela Chizomam Daniel \\ Women Entrepreneurs Association of Nigeria (WEAN) \\ E-mail: weanass@yahoo.com \\ Emmanuel Olateju Oyatoye* \\ Department of Business Administration \\ University of Lagos, Akoka, Lagos, Nigeria \\ E-mail: eoyatoye@unilag.edu.ng
}

\begin{abstract}
Like in many other developing countries of the world, poverty reduction in Nigeria remains an arduous, astounding, and formidable challenge. Poverty is viewed as multi-dimensional and multifaceted according to the type of deprivation, and also it is gender and age specific. Hence, any investigation or analysis of poverty must address the multidimensional aspect of the problem. Furthermore, investigation of poverty reduction strategies should be multidisciplinary since many different kind of change is entailed due to the fact that there is no universally applicable strategy for the reduction of poverty affecting different people in different circumstances, and in different places over time. Thus, this requires understanding the distributional effects of macroeconomic policies; the focus and efficiency of public expenditures; and the effectiveness of government program and institutions.

Poverty could be depicted as a social, economic, political, cultural, and other forms of deprivation that affect individuals, households, a segment of the population and/or communities. This study employs the analytic hierarchy process (AHP) in the evaluation of the strategies for strengthening the capacity of 'grass roots' women in Nigeria to overcome poverty.
\end{abstract}

Keywords: analytic hierarchy process, evaluative tool, strategies, strengthening capacity, grass roots women, overcome poverty.

\section{Introduction}

An individual man or woman is considered poor if they do not have access to such economic and productive resources as enough land, income or other resources to satisfy their basic needs and as a result live in precarious conditions. Poverty is said to exist when a person or sub-group of people fall below a certain level of economic well-being considered constituting a reasonable minimum, either in some absolute sense or by the standards of a given society.

Nigeria is the giant of Africa, with enviable resources. With a population of over 151 million people [UNDAF Report, 2007]; it is the most populous country in sub-Sahara Africa, and one of the leading oil producer in Africa. Together, the combination should produce economic leadership and dynamic growth. The missing link is the systematic utilization of these resources in a reliable and stable framework [World Bank Report, 1990]. In Nigeria as in other developing

African countries, women have inferior social status to men - a situation foisted and encouraged by agelong traditional system. Nigeria women perform five multiple roles - mothers, producers, home managers, community organizers and social, cultural and political leaders [UNADF Report]. Women

\footnotetext{
${ }^{*}$ Corresponding author
} 
generally contribute substantially to national economic outputs as entrepreneurs, consumers and workers predominantly in the informal sectors. Grassroots women bear excessive burden in fetching and carrying water and wood for fuel, in hoeing and weeding, harvesting, transporting, storing and food processing. Little wonder then that women and households headed by women are frequently the most chronically poor within grassroots communities. Igbedioh [1998] disclosed that one of the unique characteristics of poverty in Nigeria is the existence of disparities between males and females. Women have lower social status than men and consequently less access to schooling and training, particularly in childcare and health practices.

\subsection{Problem analysis}

It would not be out of place to expect that Nigeria would have intensified efforts in the battle against poverty in pursuit of the Millennium Development Goals and targets, which in September 2000 came from the Millennium Declaration [Human Development Report 2007/2008] signed by 189 countries with 147 Heads of government, Nigeria inclusive, in attendance. The goals and targets are interrelated and should be seen as a whole. Nigeria's progress in pursuit of these goals and targets, particularly poverty reduction has been very minimal. With less than five years to the target date, it can be said that Nigeria is not on course to reach any of the MDGs by the 2015 deadline. What would have matters most by now is that the initiatives that poverty reduction stakeholders undertake are relevant to the challenges, responsive to the right segment (grassroots women) of the population, and critically incorporated into policy frameworks. But this is yet to be seen in practical terms from whatever dimension.

Recognizing the unwholesome effect of poverty among Nigerians over the years, successive governments in Nigeria recognized poverty as the most debilitating and pervasive problem confronting the citizens and have tried to address the problem through one policy intervention or another. The previous attempts at poverty reduction in the country applied one or a combination of the economic growth strategy, the basic needs approach or the rural development approach. These interventions were packaged in programs and institutional arrangements of one form or another. In 2004, a reform agenda for the economy, political system and government institutions, including significant anti-corruption measures, was put forward as Nigeria's home-grown poverty reduction strategy, for which the government produced the National Economic Empowerment and Development Strategy (NEEDS). Though NEEDS appeared to have provided an ambitious framework for positive change focused on macro-economic reform and economic growth as the fundamental building blocks for poverty reduction, it cannot be said to have brought in the desired results. The failure of NEEDS necessitates this research work of identifying the critical criteria, sub-criteria, factors and alternatives that are essential in poverty reduction strategies among rural women in Nigeria.

\section{Literature review}

The World Bank tried to focus on poverty reduction in Nigeria during the regime preceding the 19992003, and so commissioned a study on poverty assessment in Nigeria [Human Development Report, 2001]. The study showed that poverty level in Nigeria has been extremely high, with about two thirds of the population living below the poverty line in 1996. The 2010 World Development Report shows that Nigeria's population earning below $\$ 1.25$ a day was $68.5 \%$ with a poverty gap at $\$ 1.25$ a day of $32.1 \%$, while the population earning below $\$ 2.0$ a day was $86.4 \%$ according to the survey conducted during 2003 - 2004. All indications point to the fact that Nigeria has gradually deteriorated from an advantage and manageable stage to a worrisome stage.

Poverty is a complex and heterogeneous phenomenon which embraces all aspects of life, from low income, low food consumption, ill-health, reduced life expectancy, poor education, lack of economic and productive assets, limited access to natural resources, to lack of political voice, low social status, and poor access to services and facilities. According to Mabogunje [1999], poverty can be defined in relation to four defining vectors in the matrix of individual life chances, namely the: economic, social, 
environmental and governance vectors. Whitehead [2003] opined that poverty reduction strategy papers/programs (PRSP) should be based on a multidimensional view of poverty, while better integrating the non-economic dimensions of poverty with the economic dimensions, and giving space to the views of poor men and women about their own poverty. PRSPs are required to be result-oriented, focusing on outcomes that would benefit the poor; take a holistic long term perspective; and stress transparency and accountability. Enkhbayar (2001) noted that fighting poverty is a complex task that requires complete mobilization of every potential the society possesses. As Brown [2001] highlighted in the UNDP's Human Development Report, "the poor themselves often allude to the importance of non-material deprivation". Successive Nigerian governments have proffered several poverty reduction strategies to improve the welfare of the citizenry; however, none of the various strategies succeeded in achieving the main objective.

\section{Methodology}

Survey research methodology was employed in this study. Information was generated through four different modes: communities and towns meetings; informal focused group discussions; personal interviews; and distribution of questionnaires by using a well structured questionnaire with open-ended questions. Forty two community and towns groups meetings from twenty two of the thirty six states in the country were consulted in the research process. Questionnaire was directed to the focused group (grassroots women) and stakeholders connected with poverty reduction programs. A total of 1010 questionnaire was distributed out of which 747 responses were retrieved. However, only 638 questionnaires were fully and satisfactorily completed for our AHP analysis.

The main goal of the AHP model is achieving the most reliable strategies for grassroots women to overcome poverty, with income poverty and human poverty as criteria. Under the two criteria are subcriteria which include economic, social, environmental, governance, and institutional. Alternatives used in evaluating these sub-criteria were classified into alternatives A and B as shown in the appendix.

\section{Analysis of responses on AHP criteria, sub-criteria and alternatives}

With the Expert Choice software generated pair-wise comparison matrices and synthesis of the data collected from the respondents, the pair-wise comparison matrix for the criteria, sub-criteria factors, and alternatives A and B were obtained with their respective inconsistency ratios. Mathcard software was used to compute the eigen values and eigenvectors which aided the computation of the consistency indices and consistency ratios of the pair-wise comparison matrices. In all the computations, it was found that the consistency ratio was less than 0,1 , which implies that the judgmental values given by the respondents is consistent. In other word, the small variables in the computation of eigen values and eigenvectors keep the largest eigen values $\lambda_{\max }$ close to $\mathrm{n}$ (where $\mathrm{n}$ is the number of the square matrix) and the remaining eigen values close to zero. The highest eigen values $\left(\lambda_{\max }\right)$ were used to calculate the consistency index given as:

$$
\mathrm{CI}=\underline{\lambda_{\max }} \frac{-\mathrm{n}}{\mathrm{n}-1}
$$

while $\mathrm{CI}$ is used to calculate the consistency ratio given as:

$$
\mathrm{CR}=\mathrm{CI} / \mathrm{RI}
$$

where $\mathrm{RI}$ is the random index given as: $\mathrm{RI}=1.99(\mathrm{n}-2) / \mathrm{n}$

For each of the matrices, where the $\mathrm{CI}$ and $\mathrm{CR}$ are $\leq 0.1$, it is assumed that the judgemental values of the respondents are consistent. The matrices with their respective priorities confirmed to be consistent were then used in the analysis of the data generated from the respondents with respect to the goal of the study. However, we cannot display all the computations of the priority values because of the constraint on the number of pages. Hence the analysis of the model results is based on the summary of our findings as shown in table 4.1 . 


\subsection{Model analysis}

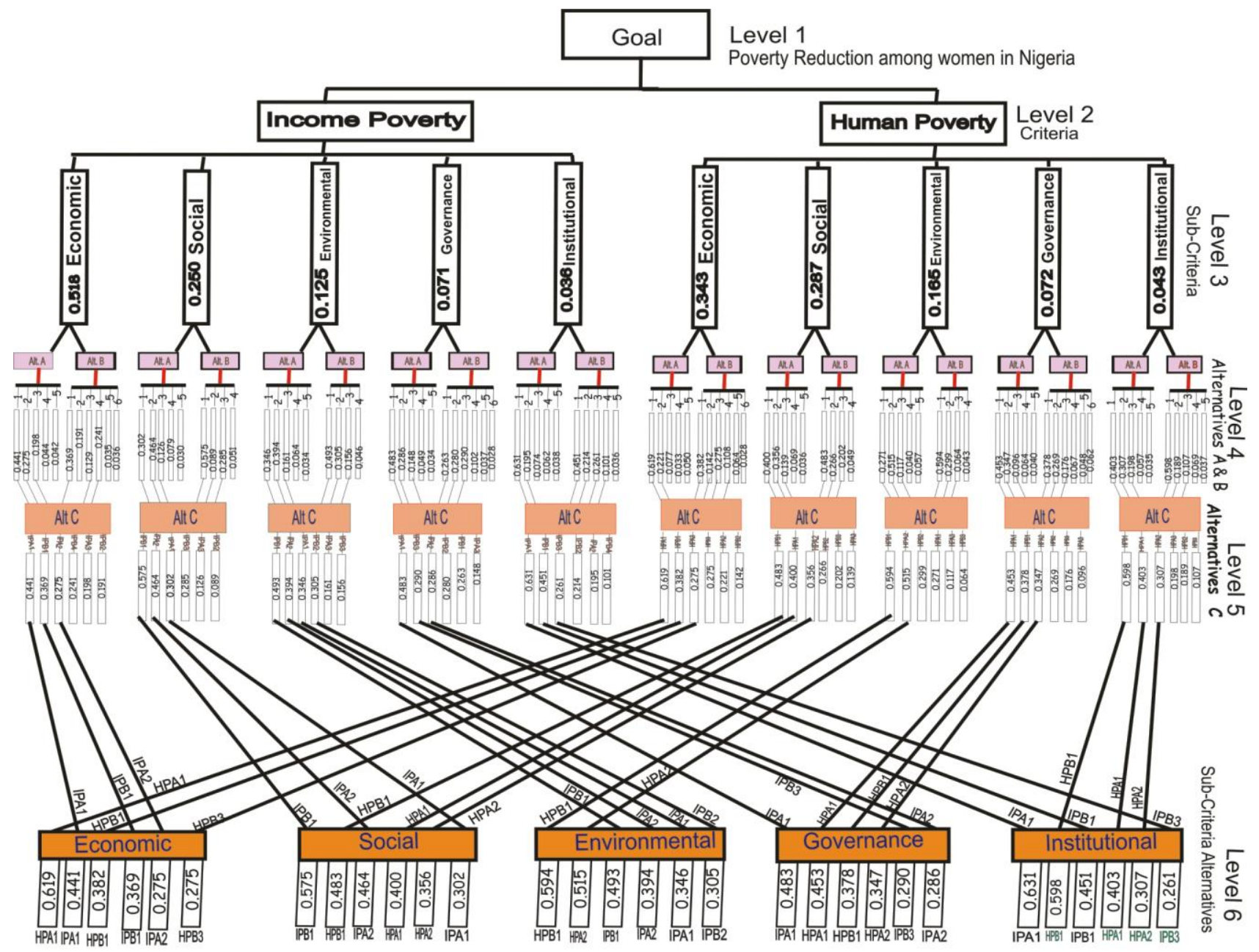

Fig. 4. 1: AHP Model for the Project

Fig. 4.1: AHP Model for the project

While figure 4.1 displays the hierarchical structure of the model, table 4.1 gives a summary of our findings which could not be displayed on separate tables. From the synthesis, access to economic/productive resources like land, credit facility, electricity, good roads, and markets seems to be the most critical for poverty reduction with a priority value of 0.631 and 0.619 as obtained under income poverty and human poverty, respectively, of the model. Next to these are opportunities for training and capacity building in relevant vocational skills for women in consideration of institutional factors, and provision of decent housing facilities under environmental factors, with priority 0.598 and 0.594 , respectively, both of which fall under human poverty. Access to economic/productive resources under income poverty ranked $5^{\text {th }}$. with a priority value of 0.575 ; while educational attainment, maternal health care services, information and knowledge facilities, recreational facilities, as well as skills and training programs under human poverty criterion ranked $6^{\text {th }}$ with a priority of 0.515 . The next eleven 
ranks were occupied by access to economic/productive resources and educational attainment, maternal health care services, information and knowledge facilities, recreational facilities vocational skills and training programs under income poverty and human poverty at various levels of priorities. All other findings are as displayed in table 4.1.

Table 4:1 Ranking of the Sub-Criteria Alternatives according to Priorities

\begin{tabular}{|c|c|c|c|}
\hline Code & Sub-Criteria Alternatives & Priorities & Ranking \\
\hline IPA1 & $\begin{array}{l}\text { Access to Economic/productive Resources: land, Credit } \\
\text { facility, Electricity, Good Roads, Markets }\end{array}$ & 0.631 & 1 \\
\hline HPA1 & $\begin{array}{l}\text { Access to Economic/productive Resources: land, Credit } \\
\text { facility, Electricity, Good Roads, Markets }\end{array}$ & 0.619 & 2 \\
\hline HPB1 & $\begin{array}{l}\text { Opportunities for Training and capacity building in relevant } \\
\text { vocational skills for women in consideration of institutional } \\
\text { factors; }\end{array}$ & 0.598 & 3 \\
\hline HPB1 & $\begin{array}{l}\text { Provision of decent housing facilities under environmental } \\
\text { factors; }\end{array}$ & 0.594 & 4 \\
\hline IPB 1 & $\begin{array}{l}\text { Access to economic/productive Resources: land, Credit } \\
\text { facility, Electricity, Good Roads, Market facilities }\end{array}$ & 0.575 & 5 \\
\hline HPA2 & $\begin{array}{l}\text { Educational Attainment, Maternal Health Care services, } \\
\text { information and knowledge facilities, Recreational facilities, } \\
\text { as well as skills and training programmes }\end{array}$ & 0.515 & 6 \\
\hline IPB 1 & $\begin{array}{l}\text { Access to economic/productive Resources: land, Credit } \\
\text { facility, Electricity, Good Roads, Market facilities }\end{array}$ & 0.493 & 7 \\
\hline IPA1 & $\begin{array}{l}\text { Access to Economic/productive Resources: land, Credit } \\
\text { facility, Electricity, Good Roads, Markets }\end{array}$ & 0.483 & 8 \\
\hline HPB1 & $\begin{array}{l}\text { Access to economic/productive Resources: land, Credit } \\
\text { facility, Electricity, Good Roads, Market facilities }\end{array}$ & 0.483 & 8 \\
\hline IPA2 & $\begin{array}{l}\text { Educational Attainment, Maternal Health Care services, } \\
\text { information and knowledge facilities, Recreational facilities, } \\
\text { Vocational skills and training programmes }\end{array}$ & 0.464 & 10 \\
\hline HPA1 & $\begin{array}{l}\text { Access to Economic/productive Resources: land, Credit } \\
\text { facility, Electricity, Good Roads, Markets }\end{array}$ & 0.453 & 11 \\
\hline IPB 1 & $\begin{array}{l}\text { Access to economic/productive Resources: land, Credit } \\
\text { facility, Electricity, Good Roads, Market facilities }\end{array}$ & 0.451 & 12 \\
\hline IPA1 & $\begin{array}{l}\text { Access to Economic/productive Resources: land, Credit } \\
\text { facility, Electricity, Good Roads, Markets }\end{array}$ & 0.441 & 13 \\
\hline HPA1 & $\begin{array}{l}\text { Access to Economic/productive Resources: land, Credit } \\
\text { facility, Electricity, Good Roads, Markets }\end{array}$ & 0.403 & 14 \\
\hline HPA1 & $\begin{array}{l}\text { Access to Economic/productive Resources: land, Credit } \\
\text { facility, Electricity, Good Roads, Markets }\end{array}$ & 0.400 & 15 \\
\hline IPA2 & $\begin{array}{l}\text { Educational Attainment, Maternal Health Care services, } \\
\text { information and knowledge facilities, Recreational facilities, } \\
\text { Vocational skills and training programmes }\end{array}$ & 0.394 & 16 \\
\hline HPB1 & $\begin{array}{l}\text { Access to Economic/productive Resources: land, Credit } \\
\text { facility, Electricity, Good Roads, Markets }\end{array}$ & 0.382 & 17 \\
\hline HPB1 & Opportunities for political participation and participation in & 0.378 & 18 \\
\hline
\end{tabular}




\begin{tabular}{|c|c|c|c|}
\hline & decision making processes & & \\
\hline IPB 1 & $\begin{array}{l}\text { Access to economic/productive Resources: land, Credit } \\
\text { facility, Electricity, Good Roads, Market facilities }\end{array}$ & 0.369 & 19 \\
\hline HPA2 & $\begin{array}{l}\text { Educational Attainment, Maternal Health Care services, } \\
\text { information and knowledge facilities, Recreational facilities, } \\
\text { as well as skills and training programmes }\end{array}$ & 0.356 & 20 \\
\hline HPA2 & $\begin{array}{l}\text { Educational Attainment, Maternal Health Care services, } \\
\text { information and knowledge facilities, Recreational facilities, } \\
\text { as well as skills and training programmes }\end{array}$ & 0.347 & 21 \\
\hline IPA1 & $\begin{array}{l}\text { Access to Economic/productive Resources: land, Credit } \\
\text { facility, Electricity, Good Roads, Markets }\end{array}$ & 0.346 & 22 \\
\hline HPA2 & $\begin{array}{l}\text { Educational Attainment, Maternal Health Care services, } \\
\text { information and knowledge facilities, Recreational facilities, } \\
\text { as well as skills and training programmes }\end{array}$ & 0.307 & 23 \\
\hline IPB2 & Provision of safe drinking water & 0.305 & 24 \\
\hline IPA1 & $\begin{array}{l}\text { Access to Economic/productive Resources: land, Credit } \\
\text { facility, Electricity, Good Roads, Markets }\end{array}$ & 0.302 & 25 \\
\hline IPB3 & Provision for social security & 0.290 & 26 \\
\hline IPA2 & $\begin{array}{l}\text { Educational Attainment, Maternal Health Care services, } \\
\text { information and knowledge facilities, Recreational facilities, } \\
\text { Vocational skills and training programmes }\end{array}$ & 0.286 & 27 \\
\hline IPA2 & $\begin{array}{l}\text { Educational Attainment, Maternal Health Care services, } \\
\text { information and knowledge facilities, Recreational facilities, } \\
\text { Vocational skills and training programmes; }\end{array}$ & 0.275 & 28 \\
\hline HPB3 & Access to Microcredit facility for micro- business activities; & 0.275 & 28 \\
\hline IPB3 & Access to Labour and employment opportunities for women & 0.261 & 30 \\
\hline
\end{tabular}

\section{Conclusion}

With the results obtained from the AHP model, any government that is serious about addressing the poverty situation should view poverty as multi-dimensional. Though only income and human poverty were considered as the main criteria in this study, some other criteria could be added in future research work. However, this study has shown that the analytic hierarchy process is a versatile tool for evaluating criteria, sub-criteria, and alternatives that could be adopted for poverty reduction strategies.

\section{REFERENCES}

Brown S. (2001). Governance and human poverty. UNDP Choice Magazine, September Issue, 8.

Enkhbayar N. (2001). Partnership to fight poverty. UNDP Choice Magazine, September Issue, 56.

Igbedioh S. O. (1998). Nutritional and policy implications of women workload and time allocation on household caring capacity. Workshop Report on Policy Implications and Influence of Time Allocation and Workload of Women on Household Caring Capacity and Urban Violence in Oyo State, Publisher by Friedrich Ebert Foundation, Lagos, Nigeria, 78. 
International Bank for Reconstruction and Development/The World Bank: Development and climate change. World Development Report 2010, Washington DC, 381.

Mabogunje A. L. (1999). Prolegomenon to urban poverty in Nigeria. Proceedings of the 1975 Annual Conference of the Nigeria Economics Society, 13-18.

Whitehead A. (2003). Failing women, sustaining poverty: Gender in poverty reduction strategy. Paper Report for the UK Gender and Development Network.

World Bank: World Development Report 1990, 24-29.

World Bank: The millennium declaration's goals for development and poverty eradication. Human Development Report 2001, 21-22.

UNDAF: Reducing poverty in Nigeria 2002-2007. UNDAF Report 2007, 23.

APPENDIX

Table 4.8 Key to the Research Model: Criteria and the Sub-criteria Alternatives

\begin{tabular}{|c|c|c|}
\hline \multicolumn{3}{|c|}{ Income Poverty Sub-criteria Alternatives } \\
\hline Code & Abbreviations & Factors \\
\hline \multicolumn{3}{|c|}{ Sub-criteria Alternatives A } \\
\hline IPA1 & 1. Eco. \& PR & \multirow{5}{*}{$\begin{array}{l}\text { Economic } \\
\text { Social, } \\
\text { Environmental, } \\
\text { Governance, } \\
\text { Institutional }\end{array}$} \\
\hline IPA2 & 2. Edu. \& HC, I\&K, RF & \\
\hline IPA3 & 3. DH \& SDW & \\
\hline IPA4 & 4. PP, PS, SS, HIS, BIG, OAA & \\
\hline IPA5 & 5. Training, J\&E, Tax Rebates, & \\
\hline \multicolumn{3}{|c|}{ Sub-criteria Alternatives B } \\
\hline IPB1 & 1.Econ \& PR & \multirow{6}{*}{ Economic } \\
\hline IPB2 & 2.Wage income & \\
\hline IPB3 & 3.Credit facility & \\
\hline IPB4 & 4.Electricity & \\
\hline IPB5 & 5.Access Roads & \\
\hline IPB6 & 6.Markets & \\
\hline IPB1 & 1.Educational Attainment & \multirow{4}{*}{ Social } \\
\hline IPB2 & 2.Maternal Health Care services & \\
\hline IPB3 & 3.Information \& Knowledge & \\
\hline IPB4 & 4. Recreational facilities & \\
\hline IPB1 & 1. Decent Housing & \multirow{4}{*}{ Environmental } \\
\hline IPB2 & 2. Safe water & \\
\hline IPB3 & 3. Sanit. \& waste Disposal & \\
\hline IPB4 & 4. Access to Electricity & \\
\hline IPB1 & 1. Pol. Part. and Dec. Making & \multirow{4}{*}{ Governance } \\
\hline IPB2 & 2.Personal Security & \\
\hline IPB3 & 3. Social Security & \\
\hline IPB4 & 4. Health Ins. Scheme & \\
\hline
\end{tabular}




\begin{tabular}{|c|c|c|}
\hline IPB5 & 5. Basic Income Guaranty & \\
\hline IPB6 & 6. Old Age Allowance & \\
\hline IPB1 & 1.Training/Capacity Building & \multirow{5}{*}{ Institutional } \\
\hline IPB2 & 2.Justice \& Equity & \\
\hline IPB3 & 3.Labour \& Employment & \\
\hline IPB4 & 4.Comm. \& Enlightenment & \\
\hline IPB5 & 5.Tax Considerations & \\
\hline \multicolumn{3}{|c|}{ Human Poverty Sub criteria Alternatives } \\
\hline \multicolumn{3}{|c|}{ sub-criteria Alternatives A } \\
\hline HPA1 & 1. Eco. \& PR & \multirow{5}{*}{$\begin{array}{l}\text { Economic } \\
\text { Social, } \\
\text { Environmental, } \\
\text { Governance, } \\
\text { Institutional }\end{array}$} \\
\hline HPA2 & 2. Edu. \& HC, I\&K, RF & \\
\hline HPA3 & 3. DH \& SDW & \\
\hline HPA4 & 4. PP, PS, SS, HIS, BIG, OAA & \\
\hline HPA5 & 5. Training, J\&E, Tax Rebates, & \\
\hline \multicolumn{3}{|c|}{ Sub-criteria Alternatives B } \\
\hline HPB1 & 1.Econ \& PR & \multirow{6}{*}{ Economic } \\
\hline HPB2 & 2. Wage income & \\
\hline HPB3 & 3. Credit facility & \\
\hline HPB4 & 4. Electricity & \\
\hline HPB5 & 5.Access Roads & \\
\hline HPB6 & 6. Markets & \\
\hline HPB1 & 1.Education Attainment & \multirow{4}{*}{ Social } \\
\hline HPB2 & 2.Maternal Health Care & \\
\hline HPB3 & 3.Info \& Knowledge & \\
\hline HPB4 & 4.Recreational facilities & \\
\hline HPB1 & 1.Decent Housing & \multirow{4}{*}{ Environmental } \\
\hline HPB2 & 2.Safe water & \\
\hline HPB3 & 3.Sanit. \& waste Disposal & \\
\hline HPB4 & 4.Access to Electricity & \\
\hline HPB1 & 1. Pol. Part. and Dec. Making & \multirow{6}{*}{ Governance } \\
\hline HPB2 & 2.Personal Security & \\
\hline HPB3 & 3.Social Security & \\
\hline HPB4 & 4.Health Ins. Scheme & \\
\hline HPB5 & 5.Basic Inc. Guaranty & \\
\hline HPB6 & 6.Old Age Allowance & \\
\hline HPB1 & 1.Training \& Capacity Building & \multirow{5}{*}{ Institutional } \\
\hline HPB2 & 2.Justice \& Equity & \\
\hline HPB3 & 3.Labour \& Employment & \\
\hline HPB4 & 4.Comm. \& Enlightenment & \\
\hline HPB5 & 5.Tax Considerations & \\
\hline
\end{tabular}

